Leach, Tony ORCID:

https://orcid.org/0000-0002-1021-6361 (2017) 'Cooling out the marks': the ideology and politics of vocational education in an age of austerity. Research in Post Compulsory Education, 22 (2). pp. 221-236.

Downloaded from: http://ray.yorksj.ac.uk/id/eprint/2355/

The version presented here may differ from the published version or version of record. If you intend to cite from the work you are advised to consult the publisher's version: http://dx.doi.org/10.1080/13596748.2017.1314681

Research at York St John (RaY) is an institutional repository. It supports the principles of open access by making the research outputs of the University available in digital form. Copyright of the items stored in RaY reside with the authors and/or other copyright owners. Users may access full text items free of charge, and may download a copy for private study or non-commercial research. For further reuse terms, see licence terms governing individual outputs. Institutional Repository Policy Statement

\title{
RaY
}

Research at the University of York St John

For more information please contact RaY at ray@yorks.ac.uk 


\title{
'Cooling out the marks': the ideology and politics of vocational education in an age of austerity
}

\section{Tony Leach}

York St John University, York, UK

School of Education

Lord Mayor's Walk

YO31 7EX

\section{Email: t.leach@yorksj.ac.uk}

To cite this article: Tony Leach (2017) 'Cooling out the marks': the ideology and politics of vocational education in an age of austerity, Research in Post-Compulsory Education, 22:2, 221-236, DOI: 10.1080/13596748.2017.1314681

To link to this article: http://dx.doi.org/10.1080/13596748.2017.1314681

\begin{abstract}
As cuts in public sector funding continue to affect the lives and careers of public sector workers in the UK, and in other countries, there are added pressures on educational establishments to equip students with the knowledge and skills for employability, sustainable employment and career development in an employment marketplace characterised by neoliberal principles and practices. In this new era of austerity, the empirical research for this paper is focused on the career experiences of graduate employees working in the public sector. The paper examines the contested ideology and politics of vocational education. Specifically, it argues that the policydriven discourse on vocational education informs a 'cooling out' process that deflects attention away from structural weakness in the economy, and disavows the impact of major changes in labour market conditions and in employer-employee relationships. This cooling out process, whereby individuals are made morally responsible to make something of their lives, in contexts where opportunities to do so are increasingly reduced, perpetuates ideological fantasies of individual aspiration and opportunity that amount to a form of 'cruel optimism.' The paper ends with the case for a robust, research-informed debate about the contested purpose of postcompulsory education in the $21^{\text {st }}$ century, the processes of psychological contracting between students and staff in colleges of further education and universities, and how contractual expectations and beliefs change over time
\end{abstract}

Keywords: Erving Goffman, vocational education, austerity, ideological fantasy, career transitions, psychological contracts

\section{Introduction}

This paper contributes to the contested body of work about the ideology and politics of vocational education in the $21^{\text {st }}$ Century. The notion that education should serve the needs of the business community and the economy is not new. Reflecting on the needs of the economy at that time, the speech given by the Labour Prime Minister James (Jim) Callaghan in Ruskin College Oxford on $18^{\text {th }}$ October 1976 is widely regarded as having begun 'The Great Debate' about the nature and purpose of public education in the UK (Callaghan 1976). Although there is very little 
research evidence of a direct correlation between education and the economy, taxation has long been used to fund the expansion of education in schools, colleges and universities in the UK, and in other countries, with the expectation that it would deliver a knowledgeable and skilled workforce; economic growth, continuous employment and prosperity for most people, and greater social equality. (Avis and Orr 2016; Bergmo-Prvulovic 2014; Haywood 2004; Keep and Mayhew 2014). Looking back to the period of post-war economic expansion in the 1950s and 1960s, optimism was justified. For many, there was the possibility of a 'job for life' with the prospect of promotion into higher paid positions within the organisation's 'internal labour market.' It was also a time when theories about the existence of a psychological contract to explain social exchange relationships in the work place first took hold. Introduced by Argyris (1960), and then taken up shortly afterwards by Levinson et al. (1962, 21) and Schein ([1945], 1980), classical definitions of the psychological contract are: that it is implicit, unwritten and often unspoken, and involves every member of the organisation; that it is concerned with perceived mutual expectations and obligations; and that these implicit understandings are about notions of mutual obligations of trust, fairness and social justice (Guest et al. 1996; Leach 2009, 2010, 2012). The parties' expectations of one another are said to be powerful determinants of job commitment and satisfaction, and commitment within the organisation. If, and when, either party reaches a point where they feel the other party is in breach of these expectations, the consequences can be serious for employer-employee relationships, employee health and wellbeing, and the organisation (Conway and Briner 2005; Conway et al. 2014; Leach 2009, 2010; Piccoli and De Witte 2015; Robinson and Rousseau, 1994; Rousseau 1995; Zhao et al. 2007)

In this new era of global economic and labour market uncertainty, there is a noticeable change in employer-employee relationship expectations. Since the 1980s, the frequency with which organisations in the public and private sector restructure their operations and the workforces has become ever more noticeable. When recessionary pressures on organisations took hold in the early 1990s, there was talk of a new version of the psychological contract, a 'new deal' with employers providing employees with work that involves skill development opportunities to maintain their employability in return for a loss of job security (Ghoshal, Bartlett and Morgan 1999; Herriot and Pemberton 1995; Rousseau 1995;). However much they were disguised, these changes were early indications of the now familiar neoliberal market fundamentalism that informs public policy for education in the UK and in other countries. The story that neoliberal market fundamentalism tells is that, free from government interference, a flexible, privatised market can resolve almost all social, economic and political problems. Within this discourse and its practices, education is regarded as a form of knowledge capital. The role of governments and others in positions of power is to ensure individuals have the knowledge, skills, powers and freedom to become innovative entrepreneurs in the competitive global market place. (CEC 2005; Davies and Bansel 2007; Harris 2007). Reflecting this narrative, excellence, performance and competitiveness have become central concepts in university teaching and research (BIS 2016; Davies and Bansel 2007; Harris 2007; Lyotard 1984). According to the logic of market fundamentalism, 'competition drives up standards' in education, resulting in higher employee knowledge and skill levels; and a belief that a more flexible labour market will increase prosperity and equality of opportunity for all. The term 'drive-up' is used to show that the 'laws' of the market are universal and unquestionable. As a consequence, the argument for the expansion of vocational education systems across the world is driven by notions of the role of education in equipping students with the knowledge, skills, powers and freedom to become innovative entrepreneurs in the competitive global market place (Com, 2005; Davies and Bansel, 2007; Harris, 2007, Keep and Mayhew 2014; Leitch Review of Skills, 2006, Lyotard, 1984). To accelerate this agenda and drive up standards in teaching to satisfy the needs of the 'knowledge economy', the UK Government's White Paper proposals for the Teaching Excellence Framework (TEF), and the creation of the Office for Students (OfS), are designed to release market forces and increase competition in Higher Education, so that 'employers get the skills 
they need at the highest level to increase productivity in their businesses’ (DBIS, 2016)

If we are to continue to succeed as a knowledge economy, however, we cannot stand still, nor take for granted our universities' enviable global reputation and position at the top of league tables. We must ensure that the system is also fulfilling its potential and delivering good value for students, for employers and for taxpayers who underwrite it. (DBIS, 2016, 5).

In keeping with this ideological and political perspective on the laws of the labour market, and the role and purpose of education, an educated person is made morally responsible for managing the development of their career throughout their working life (Bloom 2013, 788; Brooks and Everett 2009, 240; Clarke and Patrickson 2008, 122; Davies and Bansel 2007; Shamir 2008). Portrayed, as 'career actors' who can move between jobs, organisations and countries when necessary, it is claimed 'protean careerists' can repackage their knowledge, skills and abilities to remain mobile and marketable in a rapidly changing and highly competitive globalised economy (Arthur 2008; Arthur and Rousseau 1996; Hall 1996, 2002, 2004). They are said to be selfdirected and driven by values, and it is claimed their achievements are measured by psychological success rather than external rewards (Briscoe, Hall and Frautschy DeMuth 2006; Hall and Chandler 2005). It follows that the ability to be an empowered career actor in this labour market is said to be dependent on three main drivers: the individual's levels of reflexivity, self-identity and resilience (Brimrose et al. 2014, 257; Tomassini 2015, 265).

Influenced by these individualised perspectives, much of the vocational education research dwells on the experiences of successful protean careerists (Sullivan and Baruch 2009, 1550), when the reality in the contemporary context is that there appear to be two, distinctly different stories - a "good news" and a "bad news" story. According to the good news story, flexible employment arrangements enable employees to balance work, leisure and family time better, and to manage their careers more effectively. These arrangements are also said to allow managers to attract and retain skilled employees who would otherwise be unable to accept a full-time job. In contrast, the bad news story points to the harsh realities of the hollowing out of previously secure professional jobs and careers. This trend is associated with the expansion of short-term, fractional contracts, the use of agency-based contract workers, forms of self-employment, voluntary work, low pay, and a loss of employment benefits (Eliasoph 2013; Green et al. 2016; Haasler and Barabasch 2015, 310; Leach 2015; Tomassini 2015). The upshot is that questions remain over the extent to which the skills and education agenda can counteract the labour market's role as an 'inequality engine', delivering high numbers of low skill, low pay 'bad jobs' that are occupied by the many, including graduates, and high skill, high pay jobs for the privileged few (Keep and James 2012; Keep and Mayhew 2014, 776-777; Piketty 2013).

Recognising these concerns, the purpose of this paper is to consider how public sector employees react to the notion of a psychological contract breach, when their jobs and careers are put at risk in this new age of austerity. Much attention has been paid to the contested debate about the causes of the financial crash of 2007-8 and the subsequent need for cuts in public sector funding (for example, Barrrell and Davis 2008; Krugman 2015). In comparison, little attention has been given to the costly effect of austerity for public sector jobs, careers, and, more specifically, how the (so far) muted anger and dismay of those whose careers are affected by cuts in public spending is channelled and contained. To address the question of contract breach, the analysis of the findings from the research for this paper is used to further the contested debate about the role and purpose of education in the $21^{\text {st }}$ Century. Specifically, the paper argues that the current policy-driven discourse on vocational education is part of a 'cooling the mark out' process (Glynos, Klimecki, and Willmott 2012; Goffman 1952) that deflects attention away from structural weakness in the economy and disavows the impact of major changes in labour market conditions and practice, and in employer-employee relationships. The paper then concludes with 
the case for a robust, research-informed debate about the contested purpose of post-compulsory education in the $21^{\text {st }}$ century, the processes of psychological contracting between students and staff in colleges of further education and universities, and how contractual expectations and beliefs change over time

\section{The Research}

Conducted on two separate occasions, first in 2013, and then in 2015, and using email interviews, the research aims to represent and examine the participants' lived experiences when seeking to build their careers within the contemporary context of renewed cuts in public sector funding. Using this approach, each interview quickly becomes a shared asynchronous conversation, a collaborative venture during which the researcher and the research participants become co-constructors, as well as interpreters, of knowledge (James and Busher, 2009, 25). Adopting this approach can create problems in terms of eliminating researcher subjective attitudes and judgements, and when judging the authenticity of the participant's online contributions. On the other hand, Hayes (1997) reminds us that it is naïve and impractical to claim our views and attitudes have no impact on the way we interpret and understand the meanings contained in data obtained in real everyday situations.

The sample for the study comprises 12 mature graduates, whose work involves supporting vulnerable children, young people and families. Graduating in 2013, the participants (11 female and 1 male) were part-time students in their 30s and 40s, who continued with their pre-existing employment while studying for a Foundation Degree followed by a top-up BA Honours degree. Findings from the interviews conducted in 2013, were presented and discussed in an earlier paper (Leach 2015). Using extracts from the participant's narratives, obtained from follow-up interviews in 2015, the aim this time is to examine the impact of continuing austerity on their employment relationships since their graduation, and whether their reactions to changes in their employment status, and notions of a psychological contract breach, are moderated by 'cooling out' processes (Goffman 1952).

Ethical approval was obtained from the author's faculty ethics committee when planning the investigation. Known by me from the days when I was their university tutor, participants were approached via email, inviting them to take part in the study. The nature and purpose of the study were explained and, in line with common practice, they were assured their privacy and anonymity would be protected. Pseudonyms are used when quoting from the participant's narratives.

\section{Modelling the psychological contract as unscripted drama}

One of the expressed concerns regarding the notion of the psychological contract is the way much of the literature builds on a functionalist interpretation, and instrumental models, of social exchange relationships (for example, Hayes and Dyer 1999; Herriot, Manning, and Kidd 1997). When cast in instrumental terms, the notion of the psychological contract is transformed into a set of beliefs about the contract's contents. To use the concept in this way is to marginalise its distinctive explanatory powers when seeking to explain the processes wherein contractual expectations and beliefs change over time. An alternative approach is to draw on a different type of model - the dramaturgical model of social interactions. This model builds on theories of symbolic interaction (Blumer 1969), and the analogy of social behaviour as a form of unscripted drama (Goffman 1959; Perinbanayagam 1974, 1982, 1985). According to the symbolic interactionist perspective of Blumer (1969), people do not simply react, they interpret, evaluate, and define, and then act in terms of their interpretations (Caron 1995; Mead 1935). The dramaturgical perspective emphasises the importance of the subtleties, and symbolic qualities, of 
people's behaviour in organisational settings (Benzies and Allen 2001; Blumer 1969). According to this perspective, there are clear relationships between a person's behaviour, and the formal and informal roles they undertake (Friedson 1961; Goffman 1959; Hofstede 1984; John 1996). The roles people play determines the scripts they perform. Roles are part of the social structure, in that they refer to the interlocking social positions people assume within social settings. In such situations, it is more useful to think of role-related behaviour as a form of 'improvised', rather than as 'scripted', drama (McCall and Simmons 1966; Weinstein and Deutschberger 1964). Acknowledging this, and to address questions about the costly effect of austerity for public sector jobs, careers, and, more specifically, why (so far) the response from those whose careers are affected by the cuts in public spending has been muted, Goffman's essay on 'On Cooling the Mark Out' and Glynos and Howarth's (2007) 'logics approach' are used to provide an explanatory framework.

\section{The logics framework and cooling out the marks.}

The logics approach draws on a poststructuralist tradition of thought which claims structures, for example, the labour market, are socially constructed, ontologically incomplete entities, which are protected, challenged, and defended by collective acts of identification with social, political and fantasmatic logics (Bloom 2013; Glynos 2008, 277; Glynos and Howarth 2007). Used for the purposes of this paper, a distinctive feature of this logics framework is how the fantasmatic logic is seen to drive, and maintain, the emotional investment of participants in educational ventures that promise rich rewards in terms of future jobs and careers. Social logics provide synoptic descriptions or readings of social reality. Political logics, in contrast, are brought into play in moments of crisis - when things are seen to be 'not quite right' (Glynos and Howarth 2007). In such times, political logics feed processes that are intended to contest, disrupt, displace, as well as to pre-empt contestation, and maintain existing norms in labour market practice.

In deploying the logics framework, the aim is to show how, in practice, these key logics operate to channel, and contain, worker anger and dismay when the promised rewards are denied them, and they see how they have been conned. Using the terminology in Goffman's analogy, the mark is the sucker-the person who is taken in and becomes the victim of a venture that is in reality a con. When the accident occurs to highlight the venture's true character, and the victim fails to accept the 'blow-off' consequences of his loss, and complains, i.e. 'squawks', the operator of the con, on his agent, stays with the mark in order to help them to 'define the situation in a way that makes it easy for them to accept the inevitable and quietly go home.' - the 'cooling out' stage (Goffman 1952, 451). The basic phases of Goffman's model (the venture, the accident and blow-off, the squawk and cooling) are used to structure the argument. The crucial parts of the analysis concern the phases of squawking and cooling, because it is in these phases when political logics are mobilised to pre-empt contestation of the norms of policy and practice. But first, we need to focus on the venture and its origins.

\section{The venture, accident and blowoff.}

Beginning in the mid-1980s, the venture has been more than 20 years in the making, and its driving force is the logic that the 'laws' of neoliberal market fundamentalism and the flexible labour market are universal and unquestionable. After a brief lull when recessionary pressures took hold in the early 1990s, the venture assumed added impetus in the period between the mid 1990s and 2007. This is when the fantasmatic logic of 'no more bust, only boom' took hold to provide both the social and political logics with the ideological grip (Glynos 2001) that was required to promote the fantasy role of education for employability and careers (Arthur and 
Rousseau 1996; Bloom 2013; Hall 2002; Keep and Mayhew 2014; Leitch Review of Skills 2006). Critics, on the other hand, point to the insidious character of the employability and career self-mastery discourse, arguing that, far from empowering workers, it actually deepens their commitment to the venture's characteristic neoliberal ideologies and managerial demands (Bloom 2013, 786). In this contemporary context, a person's search for career fulfilment can be marked by feelings of cruel optimism and self-exploitation (Berlant 2011; Bloom 2013). Cruel optimism is the condition of maintaining an attachment to a known problematic, imaginary career ambition and its attendant promises of job satisfaction, rewards and career development, in advance of its likely loss. The cruelty is most evident when the maintenance of an attachment to the optimistic, imagined career outcome recognises its compromised conditions of possibility, but is nevertheless conceived as the reason, and means, for living in the world. (Berlant 2011). From this perspective, those who have been encouraged to take out loans to fund their education have been readily, even enthusiastically, 'taken in' (Goffman 1952, 451).

Following the 'accident' (i.e. the financial crash in 2007-8, the bail out of the banks and the onset of austerity, especially for the public sector in the UK, the cruelty of maintaining an attachment to a problematic, imaginary career ambition is all too evident in the participant's accounts. In Goffman's thesis, following the 'accident' and 'blowoff', the marks are expected to quietly go on their way, perhaps a little wiser, but nevertheless accepting their fate. With this thought in mind, it is important to note that throughout their degree course, the participants' jobs were under threat because of the cuts in public sector funding, which were introduced in 2010. It is of no surprise, therefore, that there is evidence of some 'blowoff' when the participants' express anticipatory feelings that the qualification will put them in a better position in the new, challenging environment to achieve their ambition for $\mathbf{a}$ job and a career that is central to the identities they wish to inhabit. However, participant narratives reveal the cruel reality of maintaining an attachment to the problematic, imaginary career ambition, in advance of its likely loss.

Now that I am a graduate, I feel there are many options open to me. My dream has always been to work in the education department of a museum and co-ordinate school visits and creative interactive exhibits/role playexperiences for the visiting children...but this would require further study in the form of an MA in Museum Studies, or a Primary PCGE to make myself an attractive and viable candidate for that kind of position. Currently my financial position will not allow for me to take on further study, so I feel as though I am in limbo. As for volunteering in the sector, it is difficult to get the experience in the department which would benefit me most (Ann).

Originally, I wanted to be an Early Years teacher, but, as I continued with the degree, I found myself enjoying all the new knowledge, academic writing and research too much. I wanted to keep stretching myself cognitively. I think it opened my mind to a different way of thinking that I don't really want to give up. So, I decided to go into teaching young people and adults instead. Teaching at college means I can still do a lot of the academic things I enjoy, and I really like teaching the students too. After the Post-16 PGCE I am planning on doing a Masters, but my ultimate career goal would be to work as a university lecturer. However, I am also very frustrated. In some ways, I thought that gaining a degree would open up a whole new world of work opportunities but that doesn't seem to have happened. It seems at the moment my career is dependent on factors outside of my control. (Jane)

\section{Squawking and Cooling}

Portraying their experiences, participant narratives illuminate the political and potentially hazardous realities of not being able to come to terms with, and adjust to, a never ending stream of unfinished restructures. As one participant, explained, 'we all know local authority services will be restructured again. The current restructure is my fourth in eight years.' The picture 
presented is of a service, and service personnel, whose future is full of unending contested and troublesome uncertainties. It is a story of how decisions taken in response to one set of needs can often result in 'wicked' problematic consequences and uncertainties in other areas of peoples' everyday lives (Rittel and Webber 1973; Waddock et al. 2015).

I applied for and was offered a job as a youth worker in a management position. However, I told them I would not accept it immediately as I still had other questions for them. I've looked at the funding cuts for youth services over the last three years and I had some concerns over the position and how long my contract would be for. To be fair to them, they were honest with me and said they didn't know if their jobs would be there in 12-18 months' time. If I didn't have children and a mortgage, I would have taken the risk and accepted the job. Thankfully, my manager asked if I would consider staying if they could offer me more. We discussed what I would want (more money, more responsibility, but more importantly, I would still have direct work with young people). This was agreed but I am still waiting for the confirmation and a contract to sign. I have taken on the responsibility and a much larger workload, but my wages are still the same. (Tom)

Volunteers are now drawn upon to deliver intervention work previously undertaken by paid members of staff. Case managers are now expected to train and manage volunteers as well as write specific intervention programmes. The constant 'fear' of the axe dropping and repeated consultation periods that appear to roll out annually, have meant that the service has lost a number of valued workers. The financial insecurities within the public sector do generate feelings that trained volunteers are 'apprentices waiting in the wings', particularly within an agency where it is difficult to secure paid employment. It seems as though we are educating the competition. (Clare)

As Goffman's analysis suggests, faced with the loss of an imaginary career ambition, the marks might not accept the situation and move on quietly to make room for a return to the status quo. They may be moved to complain, i.e. squawk (Goffman 1952, 451). Signalling their concerns over changes in their employment status, participants frequently use language which suggests they believe basic expectations in the psychological contract, i.e. notions of fairness and trust, are violated, and that the foundations of strong employer-employee relationships are threatened at this time.

Although my pay is protected for one year, my salary will be reduced by $£ 3500$, and my role has been down-graded so that you no long need a level 4 qualification, it is only level 3. It hasn't made me feêl valued! (Charlotte).

The perceived unfairness of this participant's situation is not just about changes in her job specification, and the impending reduction in her salary; it is also about the deliberate downgrading of her job's qualification status, as a way of absorbing cuts in public sector funding. The statement 'it hasn't made me feel valued' is especially revealing, since it resonates with the reported experiences of many public sector workers at this time. Certainly, there is some squawking in the media, and in the published research regarding the impact of the cuts in public sector funding on services, and employee job-prospects and careers (for example, Keep and Mayhew 2014; Dolton and Makepeace 2011), but there is little research to show how the apparent anger and dismay of employees is being channelled and contained.

\section{The cooling out influence of job-insecurity and a public sector commitment}

As explained earlier, crucial parts of the analysis concerning squawking and cooling are when political logics are brought into play in moments of crisis to channel and contain the squawking. In this instance, political logics operate to pre-empt contestation of a breach in the psychological contract, and to restore the mark's emotional investment in the original fantasy venture for employability and career self-mastery (Glynos and Howarth 2007). In this study, the experience of job-insecurity, and the continuing desire on the part of employees to serve members of the public, are key factor that help explain their muted reactions to the notion of a breach in the 
psychological contract between them and their employer (Conway et al. 2014). Seeing colleagues lose their jobs, and aware of the shortage of alternative employment opportunities, participant narratives reveal the psychological impact of cumulative restructures on workers' job-insecurity, and their self-protective behaviours.

Last year has been strange. It feels like everything has ground to a halt in anticipation of yet another restructure. The team is working on but in limbo. We feel dislocated from the restructure process/decisions. We don't feel there is any real consultation, just lip service. We take on tasks from former, departed colleagues, because we don't have a choice, but also because we hope that by trying to adapt, and being willing to, we will strengthen our case. We continue in the hope that we will survive intact, but in reality we all expect the opposite. We look at the internal vacancy bulletin, not for jobs, but to see what's new and what's changing. You get a taste for where things are going from the posts advertised. We scrutinise job descriptions looking for elements of our role as an indication of what might happen to us. It’s grim really. (Louise).

On the other hand, acknowledging these self-protective behaviours remind us of why the condition of maintaining an attachment to a job and career ambition is problematic (Rittel and Webber 1973; Waddock et al. 2015). The concept of a 'job for life' is no longer the norm and does not reflect the transient and complex nature of career paths that they have to follow in the 'gig economy' There is growing class of people known as the 'Precariat', who live and work precariously, often in low-paid, insecure and short term jobs (Hutton 1995; Standing 2011, 106).

\begin{abstract}
Soon after graduation, I was made redundant. I lost nine hours of contractual work with a youth club (this club closed) and for a group called Young Inspectors, which was kept running. In order to continue working with the group, I had to sign up with an employment agency that recruits casual workers for the Council. So, I am now paid hourly for this work and don't have the sameemployment benefits, although I do get paid slightly more. I enjoy the role, although it can be quite stressful, and the young people are quite vulnerable and challenging at times. Also, I gained employment at the university. The work is on a casual basis, so, again, it is not a long-term option, as I need more job security. I don't feel I have control over the direction of my career. Part of this feeling comes from being on a 'zero hours' contract, and knowing that I could suddenly be out of work with little notice and no real rights, and nothing to move on to. It is a struggle to plan things like holidays away, or time off. If I have a night off I don't get paid. I could, of course, always apply for more jobs, or widen my search to include working further afield. I have applied for many jobs since graduation and have felt disappointed many times to not get to the interview stage. In the past, when I wanted to get into a certain field, I started out volunteering and doggedly pursued the subject, reading around it and getting really into it. I don't have the motivation to volunteer anymore. When I think of developing in a particular field, I think of further study which is too expensive an option at the moment (Catherine)
\end{abstract}

The wicked reality of juggling competing requirements in their work and in their lives, is all too evident in Catherine's narrative.

\title{
Discussion and conclusions: towards a new realism
}

The focus of this paper is on the 'cooling out' processes in the employability agenda. Using Goffman's analogy of the mark and his cooling out, we can see how, when uncritically pursued, the employability agenda deflects attention away from structural weakness in the economy and disavows the impact of major changes in labour market conditions and practice, when the imagined object of desire is lost (Berlant 2011; Keep and Mayhew 2014). 
Seen in this light, participants in the study enthusiastically embarked on a three-year degree programme in 2010, in the belief that it would increase their chances of career progression and increased earnings in the occupation of their dreams - that, in Berlant's (2011) terms, it would provide them with access to 'the good life'. The efficacy of their undergraduate experience and the positive impact of becoming a graduate on their feelings of self-confidence, self-worth and enhanced ability to articulate their employment credentials with employers, colleagues and families are evident in their narratives, soon after graduation (See Leach 2015). Since then, and in different ways, the cruelty of their then optimism is now evident. The reality is etched into accounts of the changes in their employment status, brought about by waves of cuts in public sector funding. Most of all, there is an expressed feeling that some fundamental, implicit understandings of a psychological contract between them, the state and their employer are cruelly violated. These implicit understandings are about notions of mutual obligations of trust, fairness and social justice.

Recognising this raises some troublesome questions for further and higher education. Wilby (1997, 358) reminds us that the demands for more and better education to feed the needs of the economy 'is more politically palatable and less socially disruptive than direct measures for tackling inequality.' In practice, education can transform people and organisations for the better; it can also mirror and act to reproduce existing economic and social inequalities in society (Bernstein 1971; Keep and Mayhew 2014, 775). This is why the discourse about poor quality teaching, and students lacking the knowledge and skills to satisfy the economy's needs, becomes a paradigmatic target around which to re-direct and channel public outrage (Collini 2016; Palfreyman and Tapper 2014). Applying this political logic, the UK Government's White Paper's proposals for the Teaching Excellence Framework (TEF) and the creation of the Office for Students (OfS) are designed to release market forces and increase competition in Higher Education (BIS 2016). The purpose of the TEF is also to suggest, or maintain the impression, that shortcomings in HE including its lack of competitiveness, is the root problem, thus continuing to divert attention from the growth in inequality that has been a consequence of neoliberal policy and its underlying commitment to competition, which requires there to be losers as well as winners (Davis 2014). In this latest policy twist, the logic behind the original fantasy venture for employability and career self-mastery is restored (Glynos and Howarth 2007). Cast in instrumental terms, the notion of a psychological contract where the roles of students and staff are set up in opposition as customer and vendor respectively, is affirmed. Students are the customers and what they pay for, and expect, is an education that gives them advantage in the highly competitive labour market.

Understandably, in this climate, graduate employability is a significant issue, and colleges and universities are compelled to measure levels of student satisfaction, the quality of the graduate experience and their job destinations after graduation. However, the utilitarian versus the anti-utilitarian debate about the purpose of further and higher education is worthy of further exploration. Is the psychological contract between students, colleges and universities solely about equipping students for imagined, fantasy jobs and careers, or, is the relationship about more than this? As this article seeks to explain, in this age of austerity and market fundamentalism, there are no silver bullets available to guarantee success in helping students achieve their imaginary job and career outcomes. Rather, in this climate, the great danger is to over-claim what might be achievable, and then to become part of the 'cooling out the marks' process, when the victim of the con is denied the imaginary reward (Goffman 1952). Acknowledging these dangers, we can look to revisit the purpose of higher education in the $21^{\text {st }}$ century, and assert that it must be about more than just meeting the needs of modern capitalism. There are other values that are equally important. The danger is in privileging the education for the knowledge economy and employment agenda over an engagement with ideas and different ways of thinking about knowledge, and its intrinsic as well as the extrinsic value (Bernstein 2000). As well as helping serve the needs of the economy, education must also be about enabling people to become rounded citizens who 'have the capacities for reasoning, for inter-relating with other persons in 
the community and for deliberating about the ends worth pursuing' (Pring 2012, 753). It follows that there needs to be a robust, research informed debate about the processes of psychological contracting between students and staff in colleges of further education and universities, and how contractual expectations and beliefs change over time.

\section{Disclosure statement}

No personal conflict of interest was reported by the author

\section{Note on contributor}

Tony Leach $(\mathrm{PhD})$ is a senior lecturer in the School of Education at York St John University. As well as being a teacher and a supervisor of undergraduate and postgraduate research, his research and writings are focused on the topics of schools as research-informed learning communities, and graduate employment and career experiences.

\section{References}

Argyris, C. 1960. Understanding Organisational Behavior. Homewood: IL: Dorsey Press

Arthur, M. B. 2008. "Examining Contemporary Careers: A Call for Interdisciplinary Inquiry.” Human Relations 61 (2): 163-186.

Arthur, M. B., and D. M. Rousseau. 1996. "The Boundaryless Career as a New Employment Principle.” In The Boundaryless Career: A New Employment Principle for a New Organizational Era, edited by M. B. Arthur and D. M. Rousseau, 3-20. New York: Oxford University Press.

Avis, J. and K. Orr. 2016. "HE in FE: vocationalism, class and social justice.” Research in PostCompulsory Education 21 (1-2): 49-65.

Barrell, R. and E. Davis. 2008. “The evolution of the financial market crisis in 2008.” National Institute Economic Review 26 (1): 5-14.

Benzies, K.M., and M.N. Allen. 2001. "Symbolic interactionism as a theoretical perspective for multiple method research." Journal of Advanced Nursing 33(4): 54l-547.

Bergmo-Prvulovic, A. 2014. "Is career guidance for the individual or for the market? Implications of EU policy for career guidance.” International Journal of Lifelong Education, 33 (3): 376-392.

Berlant, L. 2011. Cruêl optimism. Durham: NC: Duke University Press.

Bernstein, B. 1971. “Education Cannot Compensate for Society.” New Society 15(387): 344-347.

Bernstein, B. 2000. Pedagogy, Symbolic Control and Identity: Theory, Research and Critique (revised ed.) Lanham; MJ.: Rowman and Littlefield.

Bloom, P.2013. "Fight for your alienation: The fantasy of employability and the ironic struggle for self-exploitation.” Ephemera, theory \& politics in organization, 13 (4): 785-807

Blumer, H. 1969. Symbolic Interactionism: Perspectives and Methods. Englewood Cliffs: N.J.: Prentice Hall.

Brimston. J., A. Barabasch, A., Brown, and R. Mulvey. 2014. "Mid-career changes symposium.” British Journal of Guidance \& Counselling, 43(3): 255-262.

Briscoe, J. P., D. T. Hall, and R. L. Frautschy DeMuth. 2006. "Protean and Boundaryless Careers: An Empirical Exploration.” Journal of Vocational Behavior 69 (1): 30-47.

Brooks, R., and G. Everett. 2009. "Post-graduation reflections on the value of a degree.” British Educational Research Journal 35(3), 333-349.

Callaghan, J. 1976. "A rational debate based on the facts.” Ruskin College Oxford, $18^{\text {th }}$ October 1976. http://www.educationengland.org.uk/documents/speeches/1976ruskin.html

Caron, J.M. 1965. Symbolic Interactionism: an Introduction, and Interpretation, and Integration. 
$5^{\text {th }}$ edition. Englewood cliffs, N.J.: Prentice Hall.

Communication From The Commission. 2005. Mobilizing the Brainpower of Europe: Enabling Universities to Make Their Full Contribution to the Lisbon Strategy. Brussels: European Commission. http://arhiva.tempus.ac.rs/uploads/documents/mobilizing\%20brainpower\%202005_en.pdf

Clarke, M., and M. Patrickson. 2008. “The New Covenant of Employability.” Employee Relations 30 (2): 121-141.

Collini, S. 2016. “Who are the spongers now?” London Review of Books 38(2): 33-37.

Conway, N., T. Kiefer, J. Harley, and R.B. Briner. 2014. "Doing More With Less? Employee Relations to Psychological Contract Breach via Target Similarity or Spillover during Public Sector Organisational Change.” British Journal of Management, 25: 737-754

Conway, N., and R.B. Briner. 2005. Understanding Psychological Contracts at Work: A Critical Evaluation of Theory and Research. Oxford: Oxford University Press.

Dalton, P., and G. Makepeace. 2011. "Public and private sector labour markets." In The Labour Market in Winter: The State of Working Britain, edited by P. Gregg and J. Wadsworth, 272311. Oxford: Oxford University Press.

Davies, W. 2014. The Limits of Neoliberalism: Authority, Sovereignty and the Logic of Competition. London: Sage.

Davies, B. and P. Bansel. 2007. "Neoliberalism and education". International Journal of Qualitative Studies in Education 20 (3): 247-259.

Department for Business, Innovation \& Skills (2016) Success as a Knowledge Economy: Teaching Eccellence, Social Mobility \& Student Choice, London: DBIS. https://www.gov.uk/government/uploads/system/uploads/attachment_data/file/523396/bis16-265-success-as-a-knowledge-economy.pdf

Eliasoph, N. 2013. The Politics of Volunteering. Cambridge: MA: Polity Press.

Friedson, E. 1961. Patient Views of Medical Practice. New York: Russell Sage Foundation: NY.

Ghoshal, S., S.C. Bartlett, and P. Morgan. 1999 “A new manifesto for management.” Sloan Management Review 40 (Spring): 9-20.

Glynos, J. 2001. “The grip of ideology: a Lacanian approach to the theory of ideology.” Journal of Political Ideologies 6 (2): 191-214.

Glynos, J. 2008. “Ideological fantasy at work.” Journal of Political Ideologies 13 (3): 275-296.

Glynos J., and D. Howarth. 2007. Logics of Critical Explanation in Social and Political Theory. Abingdon: Routledge.

Glynos, J., R. Klimecki, and H. Willmott. 2012. "Cooling Out The Marks: The ideology and politics of the financial crash.” Journal of Cultural Economy 5 (3): 297-219.

Goffman, E. 1952. "On cooling the mark out: some aspects of adaptation to failure. "Psychiatry 15 (4): 451 463. [Online] Available at: http://www.tau.ac.il/ algazi/mat/Goffman-Cooling.htm (accessed 22 January 2016).

Goffman E.1959. The Presentation of Self in Everyday Life. New York: Doubleday \& Co.

Green, A,, P. Sisson., K. Ray., C. Hughes, and J. Ferreira. 2016. 'Improving progression from low-paid jobs at city-region level.' A report published by Joseph Rowntree Foundation. [Online] Available at: https://www.jrf.org.uk/report/improving-progression-low-paid-jobscity-region-level

Guest, D., N. Conway., R. Briner, and M. Dickman. 1996. The State of the Psychological Contract in Employment. London: Institute of Personnel and Development.

Haasler, R., and A. Barabasch. 2015. "The role of learning and career guidance for managing mid-career transitions - comparing Germany and Denmark.” British Journal of Guidance \& Counselling 43(3): 306-322.

Hall, D. T. 1996. "Protean Careers of the 21st Century." Academy of Management Executive 10 (4): 8-16.

Hall, D. T. 2002. Careers In and Out of Organizations. Thousand Oaks: CA: Sage. 
Hall, D. T. 2004. “The Protean Career: A Quarter-Century Journey.” Journal of Vocational Behavior 65 (1): 1-13.

Hall, D. T., and D. E. Chandler. 2005. "Psychological Success: When the Career Is a Calling." Journal of Organizational Behavior 26 (2): 155-176

Harris, S. 2007. The Governance of Education: How neoliberalism is transforming policy and practice. London: Continuum.

Hayes, N. 1997. Doing Qualitative Analysis in Psychology. Hove: Psychology Press.

Hayes, N., and J. Dyer. 1999. "The Psychological Contract: all things to all people? Published in the proceedings of the BPS Occupational Psychology Conference. Blackpool 31-36.

Haywood, J. 2004. "Forward: A century of vocationalism.” Oxford Review of Education 30 (1): $1-12$.

Herriot, J., W.E. G. Manning, and J.M. Kidd. 1997. "The content of the psychological contract.” British Journal of Management 8: 151-162.

Herriot, P., and C. Pemberton. 1995. New Deals: The Revolution in Managerial Career's. Chichester: John Wiley.

Hofstede, G. 1984. Culture's Consequences: International Difference in Work-Related Values. Beverley Hills: CA: Sage.

Hutton, W. 1995. The State We're In. London: Vintage

James, N., and Busher, H. 2009. Online Interviewing. London: Sage.

John. J. 1996. "A dramaturgical view of health care service encounter: Cultural value-based impression management guidelines for medical profession behaviour.” European Journal of Marketing 30 (9): 60-74.

Keep, E., and S. James. 2012. “A Bermuda Triangle of Policy? 'Bad Jobs', Skills Policy and Incentives to Learn at the Bottom End of the Labour Market." Journal of Education Policy 27 (2): 211-230.

Keep, E., and K. Mayhew. 2014 "Inequality - 'Wicked problems'. Labour market outcomes and the search for silver bullets." Oxford Review of Education 40 (6):764-781.

Krugman, P. 2015. "The long read: The case for cuts was a lie. Why does Britain still believe it? The Austerity delusion.” The Guardian Newspaper. Accessed March 17, 2016. http://www.theguardian.com/business/ng-interactive/2015/apr/29/the-austerity-delusion

Lyotard, J. F. (1984) The Postmodern Condition: A Report on Knowledge. Manchester: Manchester University Press.

Leach, T. 2009. "Maybe I can fly: nurturing personal and collective learning in professional learning communities.” Pastoral Care in Education 27 (4): 313-323.

Leach, T. 2010. "Knowledge creation and deployment in the small, but growing, enterprise and the psychological contract.” Research in Post-Compulsory Education,15 (3): 329-344.

Leach, T. 2012. "Researching Graduates’ Lived Experiences of Vocational Learning.” Research in Post-Compulsory Education 17 (2): 261-275.

Leach, T. 2015. “Graduates' experiences and perceptions of career enactment: identity, transitions, personal agency and emergent career direction.” Research in Post Compulsory Education 20 (1): 50-63.

Leitch, S. 2006. "Prosperity for All in the Global Economy - World Class Skills. Final Report." Accessed April 1, 2014. http://www.delni.gov.uk/the-leitch-review-of-skills

Levinson, H., C.R. Price, K.J. Munden, H.J. Mandl, and C. M. Solley.1962. Men, Management and Mental Health. Cambridge, MA: Harvard University Press.

Lyotard, J. F. 1984. The Postmodern Condition: A Report on Knowledge. Manchester: Manchester University Press.

McCall, G. J., and J.L. Simmons. 1966. Identities and interactions. New York: Free Press.

Mead, G.H. 1935. Mind, Self, and Society. Edited by Charles W Morris. Chicago: The University of Chicago Press.

Palfreyman, D., and T. Tapper. 2014. Reshaping the University: The rise of the Regulated Market in Higher Education. Oxford: Oxford University Press. 
Perinbanayagam, R. S. 1974. "The definition of the situation: an analysis of the ethnomethodological and dramaturgical view.” The Sociological Quarterly 15: 521-41.

Perinbanayagam, R. S. 1982. "Dramas, metaphors, and structures.” Symbolic Interactions 5 (2): 259-76.

Perinbanayagam, R. S. 1985. Signifying Acts. Carbondale: IL: South Illinois University Press.

Piccoli, B., and H. De Witte. 2015. "Job insecurity and emotional exhaustion: Testing psychological contract breach versus distributive injustice as indicators of lack of reciprocity." Work \& Stress 29 (3): 246-263.

Piketty, T. 2013. Capitalism in the $21^{\text {st }}$ century. Cambridge: MA: Belknap Press: Harvard University.

Rittel, H. W. J., and M. M. Webber. 1973. “Dilemmas in a General Theory of Planning.” Policy Sciences 4 (2): 155-169.

Pring, R. 2012. "Putting Persons Back into Education.” Oxford Review of Education 38 (6): 747-760.

Robinson, S.L., and D.M. Rousseau. 1994. "Violating the psychological contract: not the exception but the norm.” Journal of Organisational Behaviour 15: 245-59.

Rousseau, D. M. 1995. Psychological Contracts in Organizations: Understanding Written and Unwritten Agreements. Thousand Oaks, CA: Sage.

Shamir, R. 2008. The age of responsibilization: On market-embedded morality. Economy and Society 37 (1): 1-19

Schein, E, H. (1980) Organisational Psychology ( $3^{\text {rd }}$ edition.).Englewood Cliffs: N.J.: PrenticeHall.

Standing G. 2011. The Precariat, The New Dangerous Class. London: Bloomsbury

Sullivan, S. E., and Y. Baruch. 2009. "Advances in Career Theory and Research: A Critical Review and Agenda for Future Exploration.” Journal of Management 35 (6): 1542-1571.

Tomassini, M. 2015. "Reflexivity, self-identity and resilience in career development: hints from a qualitative research study in Italy.” British Journal of Guidance \& Counselling 43 (3): 263277.

Waddock, S., G.M. Meszoely, S. Waddell, and D. Dentoni. 2015. "The complexity of wicked problems in large scale change." Journal of Organisational Change Management 28 (6):9931012.

Weinstein, E. A., and P. Deutschberger. 1964. "Tasks, bargains and identities in social interaction." Social Forces 42: 451-6.

Wilby, P. 1997. October 16. "Education and Equality.” New Statesman 358.

Zhao, H., S.J. Wayne, B.C. Glibkowski, and J. Bravo. 2007. "The impact of psychological contract breach on work-related outcomes: Meta-analysis.” Personnel Psychology, 60 (3): 647-680. 